\title{
O DIÁLOGO INTER-RELIGIOSO: RESPONSABILIDADE UNIVERSAL ENTRE HOMENS E INSTITUIÇÕES.
}

\author{
* Bruno Júnior Paz Barreto
}

\begin{abstract}
Resumo: Este artigo discute a importância da comunicação dialógica como forma de transposição de fronteiras entre as diversas tradições religiosas existentes no mundo, ou melhor, como exercer o diálogo inter-religioso no contexto do mundo globalizado onde as relações são extensivamente plurais e onde as tradições são postas em cheque, mudando seu status dentro de uma perspectiva de pluralidade, enfrentando porém o contraponto das posições acirradas, do individualismo e engendramento das posições étnicas historicamente fortalecidas pelas religiões. Nesse sentido esse texto defendo o diálogo enquanto forma única e capaz de estabelecer alternativas plausíveis na redução dos danos e da violência causada pelo acirramento do discurso religioso fundamentalista e divisório que dilacera povos e culturas. Defende-se aqui que a luta em favor da paz constitui um desafio não apenas para núcleos restritos de especialistas ou estrategistas, mas trata-se de uma "responsabilidade universal". Enfatiza-se que não se pode ser religioso driblando o caminho do humano, portanto, todo o processo ocorre a princípio em nível de conscientização humana.
\end{abstract}

Palavras-Chave: Tradições, Comunicação, Diálogo Inter-Religioso.

\begin{abstract}
This article argues the importance of the dialógica communication as form of transposition of borders between the diverse existing religious traditions in the world, or better, as to exert the Inter-religious dialogue in the context of the globalizado world where the relations are extensively plural and where the traditions are ece of fishes in check, moving its status inside of a plurality perspective, facing however the counterpoint of the incited positions, of the individualism and engendramento of the ethnic positions historically fortified by the religions. In this direction this text I defend the dialogue while it forms only e capable to establish reasonable alternatives in the reduction of the damages and the violence caused for the acirramento of the fundamentalist and dividing religious speech that dilacera peoples and cultures. It is defended here that the fight for the peace not only constitutes a challenge for restricted nuclei of specialists or strategists, but is about a "universal responsibility". It is emphasized that if it cannot be religious dribbling the way of the human being, therefore, all the process occurs the principle in awareness level human being.
\end{abstract}

Word-Key: Traditions, Communication, Inter-Religious Dialogue.

Resumen: Este artículo discute la importancia de la comunicación del dialógica como forma de transposición de fronteras entre las tradiciones religiosas existentes diversas en el mundo, o la mejora, en cuanto a ejerza el diálogo Inter-religioso en el contexto del mundo del globalizado donde están extensivamente plural las relaciones y donde están ece las tradiciones de pescados en cheque, moviendo su estado dentro de una perspectiva de la pluralidad, haciendo frente sin embargo al counterpoint de las posiciones incitadas, del individualismo y del engendramento de las posiciones étnicas fortificadas históricamente por las religiones. En esta dirección este texto defiendo el diálogo mientras que forma solamente e capaz para establecer alternativas razonables en la reducción de los daños y de la violencia causados para el acirramento del 
discurso religioso fundamentalista y que se divide que gente y las culturas del dilacera. Se defiende aquí que la lucha para la paz no sólo constituye un desafío para los núcleos restrictos de especialistas o de estrategas, pero está sobre una "responsabilidad universal". Se acentúa que si no puede ser religioso goteando la manera del humano, por lo tanto, ocurre todo el proceso el principio en el humano del nivel del conocimiento.

Palabra-Llave: Tradiciones, comunicación, diálogo Inter-Religioso.

*Bruno Júnior Paz Barreto é Graduado em Licenciatura Plena em Matemática - FAINTVISA e em Pedagogia pela - Centro Universitário Leonardo da Vinci. Possui Pós-graduação em Psicopedagogia Institucional-FATIN, Mestrado em Ciências da Religião - UNICAP. É Docente da Faculdade de Teologia Integrada-FATIN Email: brunobjp1@hotmail.com

\section{INTRODUÇÃO}

Em todos os continentes testemunha-se o acirramento da violência, que se afigura hoje como uma das mais difíceis e dramáticas questões depois do fim da guerra fria e do confronto entre Oriente e Ocidente. Os conflitos étnicos, nacionais ou sociais, estão em toda parte: na Ásia, na África, no Oriente Médio e na Europa. O confronto da tripla identidade religiosa na ex-Iugoslávia constitui um dos exemplos recentes mais dramáticos e revoltantes. Ao drama do êxodo de cerca de um milhão de kosovares de origem albanesa nesse último conflito, soma-se a "esquecida" e triste realidade dos 3,5 milhões de refugiados no continente africano.

No documento publicado pelo comitê redacional do Conselho do Parlamento Mundial das Religiões, reunido em Chicago (USA), em setembro de 1993, se dizia: Com particular inquietação constatamos que em não poucos lugares deste mundo, responsáveis e seguidores de religiões não cessam de fomentar agressões, fanatismos, ódio e hostilidade xenófoba, quando não inspiram e legitimam conflitos violentos e sangrentos.

A religião vem muitas vezes usada apenas para fins de poder político, bem como para legitimar a guerra. (KÜNG; KUSCHEL, 1995, p. 18; ver ainda KUSCHEL \& BEUKEN, 1997, p. 5; HOUTART, 1997, p. 7-17; TRACY \& HÄRING, 1998, p. 8-9) Embora se constate que a realidade da diferença esteja hoje provocando uma "espiral degenerada de comunicação", mediante o acirramento dos etnocentrismos, antipatias e ódio, devemos reconhecer que essa mesma diferença pode significar um espaço para a afirmação de um novo entendimento e solidariedade mútuos. A comunicação dialógica, como "fusão de horizontes", é uma das reais possibilidades que se apresentam hoje como pista alternativa para a humanidade. Mesmo reconhecendo a dimensão utópica de uma ordem social livre de violência, há razões plausíveis 
para se admitir esforços concretos para a redução ativa dos níveis de violência nos diversos domínios sociais (GIDDENS, 1995, p. 119-120 e p. 274-277).

Sem desconhecer a responsabilidade das religiões na atual dinâmica conflitiva contemporânea, há, porém, que sublinhar que isso ocorre em razão de sua desfiguração ou abuso teórico e prático. "As religiões podem tornar-se - e historicamente têm se tornado - um terreno especialmente propício à intolerância, por suas verdades absolutas, ortodoxias e proselitismos". Mas isso não pertence "à sua natureza; constitui antes um desvio grave do humanismo que elas implicam" (MENESES, 1997, p. 49-50).

Importantes eventos inter-religiosos, como o ocorrido em Assis (Itália) em 1986, têm favorecido uma nova esperança de diálogo e colaboração entre as religiões. Grandes lideranças religiosas mundiais têm alçado sua voz contra a presença de conflitos como os da Bósnia, Kosovo e Oriente Médio, que nascem a partir de divisões religiosas. Falando aos representantes da comunidade islâmica em 1993, João Paulo II afirmou que "a autêntica fé religiosa é uma fonte de compreensão recíproca e de harmonia, e que só a deformação do sentido religioso conduz à discriminação e ao conflito". E de forma incisiva concluiu dizendo que "usar a religião como pretexto para a injustiça e para a violência é um abuso terrível que deve ser condenado por todos aqueles que creem verdadeiramente em Deus" (PINTARELLI, 1996, p. 79).

Na mesma linha, o grande líder do budismo tibetano, o Dalai Lama, não cessa de afirmar em seus pronunciamentos e discursos "que toda religião praticada segundo o espírito que a inspira tem por objeto a felicidade dos seres e deve ser um fator de paz". Aqueles que “desnaturam o espírito de sua própria religião são os mesmos que a utilizam para fins de opressão" (REVEL, 1998, p. 115 e 153).

O diálogo inter-religioso demonstra a possibilidade de uma nova perspectiva de atuação das religiões ao reconhecer que essas podem exercer um papel significativo na construção de uma ética da superação da violência; que podem igualmente dedicar-se à tarefa comum de salvaguardar a integridade dos seres humanos e da terra ameaçada. A verdadeira relação com o Absoluto é incompatível com toda e qualquer desumanização ou violência. Essa relação, como tal, "não é violenta sob nenhum aspecto, antes pelo contrário. Ela desperta a coragem inabalável para produzir mais humanidade em todos os setores da vida" (SCHILLEBEECKX, 1997, p. 171). 


\section{O DIÁLOGO INTER-RELIGIOSO NO CONTEXTO DA GLOBALIZAÇÃO E DO NOVO MILÊNIO.}

Um dos fenômenos característicos de nosso tempo e que produz impactos decisivos sobre a religião é o dado da globalização, entendida como a afirmação de uma nova consciência global e planetária, que incide sobre a sociedade e os indivíduos. Trata-se de uma globalização intensificadora, que não se restringe a uma dimensão econômica, mas diz respeito "à transformação de contextos locais e até mesmo pessoais de experiência social" (GIDDENS, 1995, p. 13).

Atividades locais e cotidianas passam a ser influenciadas ou mesmo determinadas por acontecimentos que ocorrem do outro lado do mundo, bem como hábitos ou estilos de vida. Esse fenômeno incide igualmente sobre os sistemas de crença, cujos confins simbólicos não conseguem mais controlar suas "fronteiras". Os símbolos religiosos transgridem seus confins originários e passam a circular livremente, podendo inclusive ser utilizados por atores religiosos distintos. Com a globalização ocorre um "processo de decomposição e recomposição da identidade individual e coletiva que fragiliza os limites simbólicos dos sistemas de crença e pertencimento" (PACE, 1997, p. 32).

Diante da "contaminação cognitiva" favorecida pela globalização e a insegurança exercida pelo fato do pluralismo sobre as estruturas de plausibilidade dos sujeitos concretos, dois desdobramentos podem ocorrer. De um lado, a demarcação de identidades particulares, ou seja, o refúgio em universos simbólicos que favoreçam a impressão de uma unidade coerente e compacta da realidade social. De outro, a abertura à "mestiçagem cultural", a negociação ou intercâmbio cognitivo com o horizonte da alteridade (PACE, 1997, p. 32).

A dinâmica atual da globalização e da pluralização correlata provoca a emergência de uma “ordem social pós-tradicional” (GIDDENS, 1995, p. 13), na qual as tradições, sem perder o seu sentido de identidade, mudam de status: são discursivamente forçadas a uma exposição. Numa sociedade pós-tradicional, as identidades religiosas são permanentemente provocadas a se declararem, a entrarem em contato e a se enriquecerem com o diferente. Não há como escapar do processo permanente de redefinição da identidade e de reinvenção da tradição (ressemantização do sentido) numa sociedade plural. As mudanças em processo provocam um sério questionamento às "certezas" de fé enrijecidas ou cristalizadas. Não se trata, porém, de abandonar a tradição, mas de "reinterpretá-la" criativamente, adequando-a à situação contemporânea. 
Nessa nova perspectiva, as tradições são colocadas diante de uma dupla opção: a recusa do engajamento discursivo e da comunicação ou a abertura dialogal. A escolha da primeira opção implica muitas vezes a assunção do fundamentalismo, que consiste na "defesa da tradição de forma tradicional" (GIDDENS, 1955, p. 14), em reação às novas circunstâncias da comunicação global. A segunda opção, da comunicação dialógica, impõe-se hoje como um dos desafios mais fundamentais da humanidade. O exercício de uma comunicação dialógica implica necessariamente um deslocamento de fronteiras. Trata-se de um tema crucial para os próximos decênios: como trabalhar a questão das fronteiras com as outras tradições religiosas, ou melhor, como exercer a "arte de transpor fronteiras" (WILFRED, 1999, p. 10- 11).

A “conversação" inter-religiosa é uma realidade não só possível como fundamental no momento presente. Poucas são as conversações tão importantes, e poucas tão complexas e difíceis, já que envolvem um processo de interpretação. Quando realmente autêntica, uma conversação exige abertura à mútua transformação. Exige ainda a capacidade de reconhecer "semelhanças na diferença". Entrar em conversação é estar disposto a "arriscar toda a sua autocompreensão atual e levar a sério as posições do outro que reclama para si igual reconhecimento de autenticidade e verdade em sua auto-compreensão" (TRACY, 1997, p. 142; ver também p. 139-141).

A conversação constitui um dos mais essenciais imperativos de manutenção do sentido para os sujeitos. É mediante a conversação com os "outros significativos" que os indivíduos se apropriam do mundo, como é igualmente por ela que o mundo construído se mantém ou reconstrói sua plausibilidade (BERGER, 1985, p. 29-30; 1973, p. 202-204). Segundo a perspectiva da biologia do conhecer, trabalhada por Humberto Maturana, é na conversa que o ser humano se constitui como tal na história evolutiva. É na interação com os outros, na aceitação da singularidade dos mesmos junto a nós, no emocionar-se com eles, que brota o amor, que é fundamento do fenômeno social.

“A origem antropológica do Homo sapiens não se deu através da competição, mas sim através da cooperação, e a cooperação só pode se dar como uma atividade espontânea através da aceitação mútua, isto é, através do amor" (MATURANA, 1997, p. 185; ver também p. 174175). Um dos maiores entraves para o diálogo inter-religioso é o sentimento de predomínio sobre os outros ou a competição cega que apaga a sua singularidade única. A original reflexão de Maturana nos ajuda compreender que toda competição abafa a possibilidade do amor, gerando a cegueira e reduzindo a dinâmica de criatividade e as circunstâncias da humana convivialidade. $\mathrm{O}$ amor implica gratuidade. 
Trata-se de um "anseio biológico que nos faz aceitar a presença do outro ao nosso lado sem razão, nos devolve à socialização e muda a referência de nossas racionalizações. A aceitação do outro sem exigências é o inimigo da tirania e do abuso, porque abre um espaço para a cooperação. O amor é inimigo da apropriação" (MATURANA, 1997, p. 186). Não pode haver diálogo inter-religioso sem essa gratuita aceitação do outro, de seu envolvimento no espaço aberto do amor.

\section{A SENSIBILIDADE MACROECUMÊNICA E O CAMINHO PARA NOVOS DIÁLOGOS.}

O novo horizonte mundial não dá margens para saudosismos de outrora, que animavam o ímpeto de predomínio ou conquista do cristianismo e da Igreja católica. O quadro atual suscita mais realismo. $\mathrm{O}$ cristianismo não se expandiu por todo o planeta e as religiões mundiais dão prova de grande vitalidade.

Dados estatísticos recentes apontam um grande crescimento do Islamismo em nível mundial6 e, curiosamente, assiste-se hoje a uma inversão do antigo mapa missionário. De uma anterior expansão colonial direcionada do Norte para o Sul, verifica-se hoje um novo dinamismo que move as tradições religiosas do Oriente em direção ao mundo ocidental (GEFFRÉ, 1998, p. 56-57). Assim como se mostra problemática uma perspectiva voltada para o predomínio de uma tradição religiosa sobre as outras, revela-se igualmente frágil e utópica a perspectiva que trabalha compactuando com o mito de uma "religião mundial", que apagaria todas as diferenças e comprometeria a originalidade irredutível de cada tradição religiosa.

O que hoje se impõe como dado de maior plausibilidade é a perspectiva de um ecumenismo planetário, que retoma o sentido mesmo do termo "Ecumene", ou seja, "toda a terra habitada". Trata-se de assumir uma nova consciência macroecumênica, da profunda unidade de toda a família humana, capaz de pensar e trabalhar uma perspectiva singular de entrelaçamento global, de mútuo enriquecimento e cooperação entre as culturas e religiões em favor da afirmação de vida no mundo.

A proposta macroecumênica e do diálogo inter-religioso encontra dificuldades em determinados setores tanto da intelectualidade como das igrejas. Por razões distintas não se consegue vislumbrar o seu valor singular. Para alguns, esse diálogo não passa de mera estratégia mercadológica, para "racionalizar a própria competição na situação pluralista" (ver BERGER, 1985, p. 153; ver ainda: AUGRAS, 1997, p. 89-90). Outros tendem a entender esse processo como exigência estratégica de alargar as malhas da atuação ética e relacional da Igreja católica em face da crise da eclesialidade eurocêntrica e do vazio aberto com o ocaso do socialismo 
(PACE, 1997, p. 35-36). Em nível mais interno da Igreja católica, outras questões são levantadas. Aponta-se, sobretudo, o temor de que o diálogo inter-religioso acabe por esvaziar ou enfraquecer a tônica missionária da Igreja, acentuando um indiferentismo religioso e um relativismo problemático.

A perspectiva apontada por nosso artigo vai em outra direção, sendo capaz de reconhecer na dinâmica dialogal hoje em curso uma autêntica experiência de conversão e abertura ao mundo do outro, movida não por oportunismos táticos, mas por uma generosidade e gratuidade efetivas. A paz entre as religiões consiste em requisito essencial para a paz entre as nações. O verdadeiro diálogo inter-religioso deve ser globalmente responsável e não pode admitir a continuidade do arbítrio, da violência e o sofrimento injusto entre os seres humanos. Alimenta-se de um sonho diferente, pontuado pela dinâmica da cooperação, do entendimento e da paz. Esse diálogo torna-se, assim, portador "de novas chances não apenas para as religiões, mas igualmente para o futuro mesmo da família humana, que se interroga freqüentemente com angústia sobre o seu próprio futuro".

\section{A BUSCA PELO DIÁLOGO INTER-RELIGIOSO}

O diálogo traduz sempre uma experiência humana fundamental, uma vez que o ser humano se afirma como tal na relação com um tu (BUBER, 1977, p. 32). O diálogo diz respeito a uma reciprocidade fundamental que se instaura entre dois polos de relação: o eu e os outros. Pressupõe sempre uma semelhança e uma diferença, uma identidade e uma alteridade. $\mathrm{O}$ diálogo se instaura quando ocorre uma atitude de abertura e escuta do outro, do diferente; quando se reconhece o outro como sujeito portador de uma liberdade e dignidade fundamentais.

Dentre os diversos âmbitos de realização do diálogo podemos apontar o diálogo interreligioso, que possui sua especificidade peculiar, na medida em que os parceiros nele envolvidos pertencem a tradições religiosas distintas. $\mathrm{O}$ diálogo inter-religioso não pode ser confundido com uma mera relação de coexistência, simbiose ou confrontação de identidades distintas. Diz respeito ao "conjunto das relações inter-religiosas, positivas e construtivas, com pessoas e comunidades de outros credos para um conhecimento mútuo e um recíproco enriquecimento".

O diálogo inter-religioso implica, portanto, uma atitude de abertura somada a uma capacidade de escuta do outro. Deve, porém, ser acompanhado de um aprofundamento da própria fé. Sua grande riqueza está na partilha recíproca dos patrimônios espirituais, únicos e irrevogáveis. Na Igreja católica, uma nova atitude dialogal foi se afirmando a partir da encíclica 
Ecclesiam suam, publicada em 1964, por ocasião do pontificado de Paulo VI, e ganhou foro de cidadania no Concílio Vaticano II (1962-1965). A partir de então, aprofunda-se o empenho da Igreja em favor do diálogo, por fidelidade à própria fé (Diálogo e Missão, n. 22).

A decisão dialogal na Igreja tem suas raízes teológicas bem definidas: "nasce da iniciativa de Deus que entra em diálogo com a humanidade, e do exemplo de Jesus Cristo cuja vida, morte e ressurreição deram ao diálogo a sua última expressão" (Diálogo e Anúncio, n. 53). Embora possa ser exercido sob uma multiplicidade de formas, o diálogo é, antes de tudo, um espírito, uma atitude, um estilo de ação que deve permear todas as nossas atividades. Ele "implica atenção, respeito e acolhimento para com o outro, a quem se reconhece espaço para a sua identidade pessoal, para as suas expressões, os seus valores" (Diálogo e Missão, n. 29). Não se pode compreender a missão evangelizadora da Igreja deslocada de um espírito dialogal. Seria contrariar não somente as exigências de humanidade, mas igualmente as indicações do Evangelho. Não pode haver diálogo se não há respeito ao outro, ao mistério de sua consciência. O diálogo sincero supõe a aceitação do dado da diferença, do respeito à liberdade de consciência e religião.

Um importante documento do Concílio Vaticano II reiterou a cidadania da liberdade religiosa ao afirmar que "cada qual tem o dever e por conseguinte o direito de procurar a verdade em matéria religiosa, a fim de chegar por meios adequados a formar prudentemente juízos retos e verdadeiros de consciência" (VIER, 1968, p. 602; DH n. 3). A fidelidade ao espírito do diálogo exige de cada um de nós respeitar a presença de verdadeira liberdade em cada um de nossos interlocutores, não se admitindo em hipótese algum qualquer tipo de coação, persuasão desonesta ou constrangimento. Significa ainda respeitar "a livre decisão que as pessoas tomam em conformidade com a própria consciência” (Diálogo e Anúncio, n. 41; Diálogo e Missão, n. 18 e 19).

Com base nos pressupostos acima referenciados, o diálogo inter-religioso não pode identificar-se como mera plataforma de conversão dos outros a uma determinada religião. Ele guarda em si mesmo o seu próprio valor, não podendo ser entendido como alavanca intermediária. Se podemos falar em objetivo do diálogo, é no sentido do favorecimento de uma “conversão mais profunda de todos para Deus" e não para uma dada religião em particular.

\subsection{O ESTABELECIMENTO DO DIÁLOGO INTER-RELIGIOSO}

Para que o diálogo inter-religioso ocorra é necessário atender a algumas condições essenciais, que podemos sintetizar em cinco itens: a) a humildade; b) o reconhecimento do valor 
da alteridade; c) a fidelidade à tradição; d) a abertura à verdade; e) a capacidade de compaixão. a) Humildade - $\mathrm{O}$ diálogo exige, antes de qualquer coisa, uma disponibilidade interior de abertura e acolhimento. A humildade vem reconhecida pelo Dalai Lama como requisito favorecedor da comunicação inter-religiosa (DALAI LAMA, 1997, p. 55).

A maior resistência ao diálogo advém de pessoas ou grupos animados pela autosuficiência, pela arrogância e pela hybris totalitária. Quem está cheio de si não consegue abrir espaços para a presença dos outros. A tradição budista não cansa de enfatizar o egocentrismo e o orgulho como entraves para a dinâmica dialogal, para a aquisição da sabedoria e a disponibilidade para a compaixão. Como diz um provérbio tibetano: "a água não pode se acumular no cume de uma montanha, e o verdadeiro mérito não se amontoa sobre o pico do orgulho" (REVEL; RICARD, 1998, p. 216).

$\mathrm{Na}$ tradição cristã, Thomas Merton fala da barreira que acompanha a "heresia do individualismo". O individualismo afirma-se quando se admite a possibilidade de uma unidade inteiramente auto-suficiente, que prescinde dos outros para a sua afirmação. O espírito dialogal nos lança para além deste mundo monocromático, deste ensimesmamento, convocando-nos para a comunhão de novas fronteiras. O caminho verdadeiro, diz Merton, vai noutro sentido: “quanto mais sou capaz de afirmar os outros, dizer-lhes 'sim' em mim mesmo, descobrindo-os em mim mesmo e a mim mesmo neles, tanto mais real eu sou. Sou plenamente real se meu coração diz sim a todos" (MERTON, 1970, p. 166).

Mediante sua experiência de comunicação e comunhão com contemplativos de outras tradições religiosas, Thomas Merton pôde reconhecer a importância de "ir ainda além" de sua própria tradição, sem em nenhum momento romper com ela. De forma surpreendente e arrojada para o período afirmou: "Se eu me afirmo como católico simplesmente negando tudo que é muçulmano, judeu, protestante, hindu, budista etc., no fim descobrirei que, em mim, não resta muita coisa com que me possa afirmar como católico: e certamente nenhum sopro do Espírito com o qual possa afirmá-lo" (MERTON, 1970, p. 166).

O sentimento de superioridade e a auto-suficiência constituem reais obstáculos ao diálogo inter-religioso (Diálogo e Anúncio, n. 52; cf. SCHILLEBEECKX, 1997, p. 169), e só podem ser superados com a experiência da humildade. O diálogo começa a ocorrer quando somos capazes de reconhecer nossos próprios limites, quando assumimos uma atitude acolhedora e nos mantemos abertos, deixando-nos transformar pelo encontro. A experiência da humildade acontece quando superamos o apego excessivo e desfocamos a nossa perspectiva em direção aos outros. Isso exige um trabalho interior e paciente. $\mathrm{O}$ diálogo precisa começar dentro de nós mesmos, criando espaços livres para a hospitalidade. Para tanto, é necessário 
"fazer as pazes com nós mesmos". O diálogo com os outros flui de maneira muito mais tranqüila quando estamos em paz com nós mesmos.

A tradição mística sempre enfatizou este dado: "Para mudar a paisagem, basta mudar o que sentes". Ninguém pode arrogar-se à pretensão de ter assimilado plenamente a verdade. Com a humildade somos capazes de nos reconhecer peregrinos da verdade, juntamente com os outros, ou seja, "companheiros de uma viagem fraterna" cuja meta transcendente permanece para nós velada nesse tempo do mistério da paciência de Deus (Diálogo e Missão, n. 21 e 44). O reconhecimento e respeito à alteridade do interlocutor constitui outra das condições exigidas para um diálogo positivo com as diversas tradições religiosas. O diálogo deve ser pontuado pela "hermenêutica da diferença" e não pela "lógica da assimilação". Daí a importância da abertura desinteressada às convicções do outro e o respeito à sua identidade única e irrevogável.

Todo diálogo inter-religioso pressupõe o reconhecimento da integridade da fé dos interlocutores envolvidos no processo. Assim como os cristãos, ao entrarem no diálogo, não podem dissimular sua fé em Jesus Cristo a título de melhor probabilidade de comunhão; eles devem igualmente reconhecer nos outros "o direito e o dever inalienável de igualmente empenhar-se no diálogo conservando suas convicções próprias, inclusive as pretensões de universalidade que podem fazer parte de sua fé" (DUPUIS, 1997, p. 508).

Levar a sério as religiões é nelas reconhecer algo de irredutível e irrevogável, que jamais será tematizado ou totalizado no cristianismo. "Assim como a Igreja nascente não integrava nem substituía as riquezas do povo de Israel, assim, também hoje, o cristianismo histórico não pode ter a pretensão de integrar e substituir as riquezas autênticas das outras tradições religiosas" (GEFFRÉ, 1997, p. 133). Essas tradições são portadoras de um verdadeiro "patrimônio espiritual", não podendo ser reduzidas a experiências "naturais" ou esforços simplesmente humanos. São também portadoras dos dons que a sabedoria do Deus multiforme “escondeu na criação e na história” (Diálogo e Missão, n. 21 e 22).

O diálogo inter-religioso pressupõe um esforço dedicado em "colher a experiência do outro" em seu lugar de realização. Para que isso ocorra, é necessária uma dinâmica de empatia, de simpatia interior. É o que R. Panikkar denominou diálogo intra-religioso, condição essencial para o diálogo inter-religioso. O verdadeiro diálogo vai além de um mero conhecimento teórico da outra tradição, pressupõe igualmente um esforço positivo de habitar a experiência religiosa do outro e partilhar a sua visão complexa da realidade. Trata-se de uma tarefa extremamente complexa e difícil: de uma "comunicação em profundidade", como bem expressou Thomas Merton em seu Diário da Ásia. 
O diálogo inter-religioso pressupõe igualmente a fidelidade a si mesmo e ao próprio engajamento de fé. A sensibilidade dialogal deve ser sempre acompanhada de convicção religiosa, de um ancoradouro referencial. Não é colocando a fé singular em suspenso que se consegue chegar de forma mais profunda ao universo do outro. Essa travessia pressupõe, antes, uma clara identidade cultural e religiosa, que deve ser sempre alimentada. Não há como ser cidadão do mundo fora de um enraizamento particular.

Paul Ricoeur sublinhou de forma muito feliz a impossibilidade de um ponto de vista deslocado de referências específicas, de forma a poder abraçar a multiplicidade das religiões. A abertura dialogal sempre ocorre "no seio de um compromisso determinado". Não se pode dialogar prescindindo de uma tradição referencial: “é aprofundando meu próprio compromisso que posso encontrar aquele que, partindo de outro ponto perspectivo, realiza um movimento análogo" (RICOEUR, 1995, p. 189).

A partir de sua rica experiência de diálogo, Thomas Merton (1978, p. 248) assinala que o aprofundamento de uma comunhão intermonástica, envolvendo contemplativos de tradições diferentes, só pode ocorrer em profundidade quando acompanhada de um sério empenho de inserção na própria tradição particular (ver ainda: Diálogo e Anúncio, n. 48 e DUPUIS, 1997, p. 507-508). Essa preocupação de preservar a identidade da tradição na dinâmica dialogal ocorre igualmente em outras perspectivas religiosas.

Ao trabalhar o tema do Islã e o encontro das religiões, o estudioso Seyyed Hossein Nasr chama a atenção para o permanente dilema: permanecer fiel à própria religião e, não obstante, aceitar a validade de outras tradições. Não há, em linha de princípio, uma oposição entre a preservação da tradição e o enriquecimento advindo do contato com outras tradições. As janelas da mente devem estar sempre abertas, como as copas das árvores que se abrem no horizonte. Mas essas janelas encontram sua referência nas paredes, assim como a beleza das árvores esconde a firmeza de seu enraizamento profundo, essencial para a sua vitalidade (NASR, 1990, p. 239).

Com respeito à perspectiva do budismo tibetano, Dalai Lama acentua uma mesma preocupação. Para melhor dialogar, ninguém precisa romper com a religião de sua própria cultura e herança. São justamente aqueles que sabem encontrar e reconhecer o valor de suas próprias tradições os que "estão em melhor posição para poderem apreciar o valor e a preciosidade das outras tradições" (DALAI LAMA, 1997, p. 55).

Outra condição fundamental para o diálogo inter-religioso é a abertura à verdade. A realidade do pluralismo religioso e as novas relações inter-religiosas provocaram a retomada da 
discussão sobre a verdade da religião, entendida agora como uma realidade mais compreensiva e elevada, que transborda o caráter limitado e parcial de cada verdade particular.

A sensibilidade dialogal tem provocado o cristianismo a recuperar o sentido originário da verdade cristã, muitas vezes desfigurado em razão de uma longa tradição da dogmática cristã, que enfatizou mais o dado metafísico da verdade objetiva, pensada conforme uma lógica de proposições contraditórias. Na tentativa de estabelecer os traços essenciais da verdade do cristianismo no contexto do pluralismo religioso, o teólogo Claude Geffré destacou três elementos. Sinalizou, em primeiro lugar, que a verdade cristã pertence à "ordem do testemunho", não podendo ser afirmada senão na incondicionalidade da fé. A verdade não pode ser monopolizada por ninguém, pois não é algo que possuímos, mas "alguém por quem nos devemos deixar possuir" (Diálogo e Anúncio, n. 49).

Mostrou, em segundo lugar, que a verdade cristã é da "ordem da antecipação". Trata-se de uma verdade sob o signo do devir, como um acontecer permanente sempre aberto a realizações mais plenas. Uma verdade que reenvia sempre o sujeito ao mistério do Deus invisível, sempre maior, que escapa a toda identificação. Por fim, sublinhou que a verdade cristã é uma "verdade compartilhada", já que implica a relação com as outras tradições religiosas. Trata-se de uma verdade essencialmente relacional (GEFFRÉ, 1998, p. 142-144).

O cristianismo caracteriza-se por uma dinâmica fundamentalmente dialogal. Ele fundamenta-se no diálogo e leva ao diálogo. Sua compreensão de verdade é dinâmica e marcada pela reserva escatológica de Deus. Não pretende e nem pode pretender assumir o monopólio da verdade religiosa sobre Deus. Nesse sentido, experiências religiosas autênticas e únicas acontecem também alhures, sem que possam ser tematizadas ou praticadas no interior do próprio cristianismo. Desconhecer esse dado é arriscar comprometer a originalidade e a harmonia das riquezas do próprio cristianismo. É, pois, correto afirmar que "há mais verdade de ordem religiosa no concerto polifônico das religiões do mundo que no cristianismo, considerado em sua exclusividade" (GEFFRÉ, 1998, p. 67).

O diálogo é, assim, uma "aventura", um caminhar em comum para uma aproximação cada vez maior desse Deus que se auto comunica ao humano, mas que permanece misterioso. Não pode haver, necessariamente, apriorismos que condicionem já de partida os limites para a sua realização. Trata-se, antes, de um caminhar em que cada um dos interlocutores, permanecendo fiel à sua identidade e verdade particular, é convidado igualmente a participar de uma "celebração da verdade", que ultrapassa a particularidade específica de seus horizontes, provocando, assim, uma "recíproca conversão". 
Falar hoje em compaixão pode soar estranho aos ouvidos de alguns. Trata-se de um sentimento tão distante do modo como o ser humano vem construindo sua personalidade nesses espaços modernos propícios ao individualismo. Mas continua a ser fundamental e provocar as cordas mais profundas do espírito humano. Longe de ser identificada com um mero sentimento de piedade ou comiseração, a compaixão diz respeito ao profundo desejo de remediar todas as formas de sofrimento que corroem a humanidade e toda a criação. Como indica o Dalai Lama, a compaixão diz respeito ao movimento de expansão do amor, que busca, acima de tudo, o bemestar dos outros. Esse sentimento é mais forte do que o amor próprio e não encontra satisfação enquanto houver qualquer sofrimento.

Para Leonardo Boff, a compaixão traduz uma das ressonâncias ou concreções essenciais do cuidado, como modo essencial de ser humano no mundo. Alguém é compassivo na medida em que sai de sua própria órbita para "partilhar a paixão do outro e com o outro": estar e permanecer com ele, alegrar-se em sua presença, partilhar os seus caminhos e construir com ele um sonho alternativo (BOFF, 1999, p. 126-128).

A realidade crescente da pobreza e do sofrimento tem servido hoje de chave hermenêutica para uma nova perspectiva do diálogo inter-religioso. Um dos importantes autores que vêm trabalhando essa temática, o teólogo americano Paul Knitter, identifica a realidade do sofrimento como "terreno comum" para uma nova perspectiva dialogal. Para esse autor, "o sofrimento tem uma universalidade e uma proximidade tal que o torna lugar mais adaptado e necessário para estabelecer um terreno comum para o encontro inter-religioso" (KNITTER, 1998, p. 161).

Na mesma perspectiva insere-se um grupo de teólogos espanhóis que sugerem o tema da "universalidade do pobre" como eixo estruturador da dinâmica relacional entre as religiões da terra. É essa universalidade do pobre a convocar a atitude ativa da compaixão radical que deverá animar e unir as diversas tradições religiosas. Desloca-se, assim, a pergunta fundamental: não é mais a questão em torno da verdade mais correta, mas da caridade mais efetiva e universal (ALEGRE, 1995, p. 10 e 127-128).

\subsection{AS FORMAS DE DIÁLOGO: EM BUSCA DA TEOLOGIA E DA HUMANIDADE.}

O diálogo inter-religioso pode apresentar-se sob formas diversificadas. Uma importante forma de diálogo acontece em nível da "cooperação religiosa em favor da paz". Trata-se de um diálogo de obras, envolvendo ações e colaboração comum em favor de um mundo mais humano e justo. Talvez seja esse um dos campos onde ocorre hoje uma maior comunhão das 
experiências religiosas. Nesse campo ético transparece de forma precisa o encontro das religiões, suscitando, assim, uma nova "comunhão criatural".

A luta em favor da paz constitui um desafio não apenas para núcleos restritos de especialistas ou estrategistas, mas trata-se de uma "responsabilidade universal". Não se pode ser religioso driblando o caminho do humano. Uma outra forma de diálogo ocorre em nível dos “intercâmbios teológicos". Trata-se aqui de um diálogo envolvendo especialistas e peritos das várias tradições religiosas. O objetivo desse diálogo consiste em "confrontar, aprofundar e enriquecer os respectivos patrimônios religiosos" (Diálogo e Missão, n. 33).

Esse talvez seja o diálogo mais difícil, em que se dá propriamente o confronto das crenças singulares e respectivas experiências espirituais mais íntimas; ele pressupõe uma certa relativização das próprias crenças, a disponibilidade de colocar-se em discussão e deixar-se transformar pelo encontro. Importantes e significativos grupos de discussão inter-religiosos têm hoje se formado no mundo inteiro para o aprofundamento dessas questões teológicas.

Em um nível mais profundo, encontra-se o "diálogo da experiência religiosa". Trata-se do diálogo silencioso da oração e da contemplação. Nesse nível, dá-se o encontro de pessoas profundamente enraizadas nas suas específicas tradições religiosas para viver e compartilhar as suas experiências de oração, contemplação e fé, bem como a forma de envolvimento dessas experiências com a vida concreta.

Nesse diálogo, procura-se comungar as diversas expressões e caminhos da busca do sentido fundamental e do mistério absoluto. Os participantes nele envolvidos "não se detêm diante das diferenças", pois estão animados por um propósito mais decisivo, o de promover e preservar os valores e ideais espirituais mais sublimes do ser humano (Diálogo e Anúncio, n. 35). Nesse nível de diálogo, ocorre uma “comunhão em profundidade”, para utilizar a expressão de Thomas Merton. Uma comunhão que não se reduz a uma simples troca de conceitos ou idéias, mas que acontece "acima do nível das palavras", favorecendo uma autêntica e inusitada experiência espiritual (MERTON, 1978, p. 246-248).

Comentando sobre essas formas de diálogo, com base na experiência envolvendo as tradições cristã e budista, Dalai Lama reconheceu a presença de uma "enorme convergência e um potencial para o enriquecimento mútuo”. Ressaltou, em particular, as áreas da ética e da prática espiritual: as práticas da compaixão, da tolerância, do amor e da meditação. Reconheceu que esse diálogo "pode ir muito longe e alcançar um nível profundo de entendimento". Sublinhou ainda que no domínio da metafísica o entendimento ainda é problemático, dadas as diferenças fundamentais existentes. Isso, entretanto, não o impede de admitir que mediante o 
diálogo seja possível transcender essas diferenças e reconhecer uma base comum para o entendimento mútuo (DALAI LAMA, 1997, p. 100).

\section{CONSIDERAÇÕES FINAIS}

O diálogo favorece um novo aprendizado. Na medida em que é vivido em profundidade, os interlocutores saem enriquecidos pela aquisição dos valores positivos que animam as tradições em questão. E a própria fé sai dinamizada e mesmo purificada. O cultivo e o aprofundamento da abertura ao outro não é motivo de enfraquecimento da fé, como pensam alguns, mas fator de seu aprofundamento.

Nesse movimento, novas e inusitadas dimensões dessa mesma fé veem descortinadas (Diálogo e Anúncio, n. 50). Nessa experiência de comunhão, os interlocutores poderão descobrir em maior profundidade aspectos ou dimensões do próprio mistério divino que sua própria tradição particular não conseguiu expressar com a mesma clareza ou dimensão.

Uma outra condição para o diálogo, nem sempre acentuada, mas igualmente muito importante é a compaixão ativa. O acento dado na compaixão talvez tenha sido uma das grandes contribuições fornecidas pelo budismo a toda a humanidade. Ser alguém compassivo significa ter entranhas de misericórdia.

Somente a misericórdia, a compassividade e a alteridade possibilitam os caminhos que levarão homens e instituições ao diálogo que estabelecerá dentro do respeito à pluralidade e diversidade a capacidade do homem sentir-se uno com a sua espiritualidade e divindade.

\section{REFERENCIAS}

ALEGRE, X. et al. Universalidad de Cristo. Universalidad del pobre. Santander: Sal Terrae, 1995.

BUBER, M. Eu e tu. São Paulo: Cortez \& Moraes, 1977.

DALAI LAMA. A bondade do coração; uma perspectiva budista sobre os ensinamentos de Jesus. Lisboa: Edições Asa, 1997.

DUPUIS, J. Verso una teologia cristiana del pluralismo religioso. Brescia: Queriniana, 1997.

GEFFRÉ, C. La verdad del cristianismo en la era del pluralismo religioso. Selecciones de Teología, v. 37, n. 146, p. 142-144, 1998. 
GIDDENS, A. Para além da esquerda e da direita. São Paulo: Unesp, 1995.

HOUTART, F. O culto da violência em nome da religião. Concilium, v. 272, n. 4, p. 7-17, 1997.

KUSCHEL, K-J.; BEUKEN, W. Editorial - A violência assusta: como superá-la ? Concilium, v. 72, n. 4, p. 5, 1997.

KÜNG, H.; KUSCHEL, K-J. Per un'etica mondiale; la dichiarazione del Parlamento delle religioni mondiali. Milano: Rizzoli, 1995.

KUSCHEL, K-J.; BEUKEN, W. Editorial - A violência assusta: como superá-la? Concilium, v. 72, n. 4, p. 5, 1997.

KNITTER, Paul. 1986. “A teologia Católica das religiões numa encruzilhada". Revista Concilium. 203:103-113.

MATURANA, H. A ontologia da realidade. Belo Horizonte: Editora da UFMG, 1997.

MENESES, P. Tolerância e religiões. In: TEIXEIRA, F. (Org.). O diálogo inter-religioso como afirmação da vida. São Paulo: Paulinas, 1997. p. 49-50.

MERTON, T. O diário da Ásia. Belo Horizonte: Veja, 1978.

Reflexões de um espectador culpado. Petrópolis: Vozes, 1970.

PACE, E. Religião e globalização. In: ORO, A. P.; STEIL, C. A. Globalização e religião. Petrópolis: Vozes, 1997. p. 32.

PINTARELLI, A. E. O espírito de Assis; discursos e alocuções de João Paulo II sobre a paz. Petrópolis: Vozes, 1996.

REVEL, J. F.; RICARD, M. O monge e o filósofo; o budismo hoje. Papirus. 1997

RICOEUR, P. Em torno ao político; leituras 1. São Paulo: Loyola, 1995.

O si-mesmo como um outro. Campinas: Papirus. . 1991.

SCHILLEBEECKX, E. Religião e violência. Concilium, v. 272, n. 4, p. 170-171, 1997.

TRACY, D.; HÄRING, H. Introdução. Concilium, v. 274, n. 1, p. 8-9, 1998. 